\title{
Relationship between glucocorticoids and prolactin during mammary gland stimulation in dairy cows
}

\author{
B. Ponchon, ${ }^{*}$ X. Zhao, ${ }^{*}$ S. Ollier, $†$ and P. Lacasse ${ }^{1}$ \\ *Department of Animal Science, McGill University, Sainte-Anne-de-Bellevue, QC, H9X 3V9, Canada \\ †Sherbrooke Research and Development Centre, Agriculture and Agri-Food Canada, Sherbrooke, QC, J1M 0C8, Canada
}

\begin{abstract}
The objectives of this study were to determine the role of glucocorticoids in the regulation of prolactin (PRL) release induced by mammary gland stimulation and to investigate whether the milk depression induced by glucocorticoids in dairy cows is due to a decrease in PRL release. In experiment 1, 8 dairy cows were used in a $4 \times 4$ Latin square design. Four hours after the morning milking, the cows received 1 of the following treatments: (1) a 5-min manual stimulation of the mammary gland; (2) an i.v. injection of $1 \mathrm{mg}$ of dexamethasone; (3) 2 infusions of $2.5 \mathrm{~g}$ of metyrapone (an inhibitor of cortisol biosynthesis) in the omasum 4 and $2 \mathrm{~h}$ before a 5-min stimulation of the mammary gland; or (4) no treatment. Sixty minutes later, the mammary gland of each cow was stimulated for 5 min. Blood samples were collected from 20 min before to 120 min after the start of the treatment. When the mammary gland was stimulated twice in $60 \mathrm{~min}$, less PRL and cortisol were released during the second stimulation. Metyrapone did not affect PRL or cortisol release. Dexamethasone decreased serum cortisol concentration but did not affect PRL concentration. In experiment 2, 16 cows were used in a crossover experimental design consisting of 2 experimental weeks separated by 1 resting week. During the first week, cows were treated as follows: (1) 4 cows were injected with $0.5 \mathrm{~g}$ of domperidone (a PRL secretagogue) in canola oil on $\mathrm{d} 1$ and 2 and $20 \mathrm{mg}$ of dexamethasone on $\mathrm{d} 1$; (2) 4 cows were injected with $0.5 \mathrm{~g}$ of domperidone on $\mathrm{d} 1$ and 2 ; (3) 4 cows were injected with canola oil on d 1 and 2 and with $20 \mathrm{mg}$ of dexamethasone on d 1; and (4) 4 cows were injected with canola oil on d 1 and 2. During the second experimental week, the same 4 treatments were repeated, except the cows that did not receive dexamethasone in the first week received it on $\mathrm{d} 1$ of the second week, and cows that did receive it in the first week did not receive it in the second week. On d 1 and 2 of each week, blood
\end{abstract}

Received May 19, 2016.

Accepted November 6, 2016.

${ }^{1}$ Corresponding author: Pierre.Lacasse@agr.gc.ca samples were collected during morning milking for PRL determination. Dexamethasone reduced milk production and decreased both basal and milking-induced PRL release. It also increased milk fat and protein percentages and decreased milk lactose content. Domperidone increased basal PRL levels in serum and milk but did not affect milk yield. Although we cannot rule out the possibility that inhibition of PRL secretion or reduction of mammary gland PRL responsiveness play a role in the inhibition of milk production by glucocorticoids, the fact that enhancement of PRL secretion by domperidone could not prevent the depression of milk yield suggests that other mechanisms are involved.

Key words: milking, dexamethasone, milk production

\section{INTRODUCTION}

Prolactin (PRL) is one of the major hormones involved in the control of mammary gland functions, including galactopoiesis (Lacasse et al., 2016); this hormone is released during milking and nursing in response to mammary gland stimulation. The regulation of PRL secretion is not completely understood, however. As lactation advances, basal PRL concentration and the amount of PRL released during milking are both reduced (Koprowski and Tucker, 1973; Miller et al., 2000; Bernier-Dodier et al., 2011). As well, milking-induced PRL release in cows decreases as the interval between milkings or manual stimulations decreases (Lacasse and Ollier, 2014). The reason for reduction in PRL release during lactation or after multiple mammary gland stimulations is not known. It could be due to decreased sensitivity of the mammary skin to tactile stimulus, or to reduced responsiveness at the level of the hypothalamus or the pituitary gland.

Besides PRL, milking also induces the release of glucocorticoids, which are steroid hormones synthesized by the adrenal glands. Interestingly, adrenalectomy prevented the usual decrease in PRL levels during the second half of lactation in rats (van der Schoot and de Greef, 1983). Furthermore, female rats treated with dexamethasone, a glucocorticoid analog, exhibited a lower suckling-induced PRL response and lower milk 
Table 1. Summary of the treatments of experiment 1

\begin{tabular}{|c|c|c|c|}
\hline Treatment & \multicolumn{3}{|c|}{ Hours after morning milking } \\
\hline STIM & & $\begin{array}{l}\text { 5-min manual stimulation of the } \\
\text { mammary gland }\end{array}$ & $\begin{array}{l}\text { 5-min manual stimulation of the } \\
\text { mammary gland }\end{array}$ \\
\hline DEXA & & $\begin{array}{l}\text { Intravenous injection of } 1 \mathrm{mg} \text { of } \\
\text { dexamethasone }\end{array}$ & $\begin{array}{l}\text { 5-min manual stimulation of the } \\
\text { mammary gland }\end{array}$ \\
\hline METY & $\begin{array}{l}\text { Infusion of } 2.5 \mathrm{~g} \text { of metyrapone in } \\
\text { omasum }\end{array}$ & $\begin{array}{l}\text { 5-min manual stimulation of the } \\
\text { mammary gland }\end{array}$ & $\begin{array}{l}\text { 5-min manual stimulation of the } \\
\text { mammary gland }\end{array}$ \\
\hline
\end{tabular}

secretion compared with control animals (Horváth et al., 2001). Although glucocorticoids act in synergy with PRL to activate the gene expression of caseins (Skarda et al., 1982), their administration has also been reported to inhibit milk production in both rodents and cows (Shamay et al., 2000; Vilela and Giusti-Paiva, 2011). The mechanism by which glucocorticoids inhibit milk secretion is not known. Given the recent body of evidence supporting the galactopoietic role of PRL in ruminants (Lacasse et al., 2016), the negative effect of glucocorticoids on milk secretion may be mediated in part by the inhibition of PRL release or the reduction of mammary gland responsiveness to this hormone. However, dexamethasone has also been shown to decrease plasma IGF-1 concentrations in cows (Maciel et al., 2001). Given that IGF-1 stimulates milk yield in goats (Prosser et al., 1990), glucocorticoid-induced milk inhibition may also involve an action on IGF-1 secretion or clearance.

The objectives of this study were to evaluate the effects of glucocorticoids on milking-induced PRL release and to test whether glucocorticoid-induced inhibition of milk production is due to a reduction in PRL secretion.

\section{MATERIALS AND METHODS}

\section{Animals and Experimental Design}

The experiments were conducted at Agriculture and Agri-Food Canada's Sherbrooke Research and Development Centre (Sherbrooke, QC, Canada) in accordance with the guidelines of the Canadian Council on Animal Care. The animals were housed in a tie-stall barn and were milked twice daily at 12 -h milking intervals.

\section{Experiment 1}

We used 8 multiparous fistulated Holstein dairy cows in mid-lactation $(196 \pm 11 \mathrm{DIM})$ in a $4 \times 4$ Latin square design for this experiment. Cows were allocated to 1 of 4 groups that were balanced in terms of cows' parity, milk production, and DIM. Three days before the start of treatments, a Silastic catheter (i.d. 1.02 mm, o.d. $2.16 \mathrm{~mm}$; Dow Corning Corp., Midland, MI) was inserted into each cow's jugular vein. Each experimental day was separated by at least 2 resting days.

On each experimental day, the cows received 1 of the following treatments: (1) a 5-min manual stimulation of the mammary gland $4 \mathrm{~h}$ after the morning milking (STIM); (2) an i.v. injection of $1 \mathrm{mg}$ of the glucocorticoid analog dexamethasone (Vetoquinol, Lavaltrie, QC, Canada) $4 \mathrm{~h}$ after the morning milking (DEXA); (3) infusions of $2.5 \mathrm{~g}$ of metyrapone (Sigma-Aldrich, Oakville, ON, Canada), an inhibitor of cortisol biosynthesis, in the omasum 4 and $2 \mathrm{~h}$ before a 5 -min manual stimulation of the mammary gland $4 \mathrm{~h}$ after the morning milking (METY); or (4) no treatment $4 \mathrm{~h}$ after the morning milking (CTL). Sixty minutes after treatment, the mammary gland of each cow was manually stimulated for $5 \mathrm{~min}$. A summary of the treatments is presented in Table 1.

Blood samples were collected before, during, and after the first manual stimulation or injection $(-20$, $-10,0,3,5,7,10,15,20,25,30,40,60$ [start of the second stimulation], 63, 65, 67, 70, 75, 80, 85, 90, 100, and 120 min relative to the start of the first manual stimulation or injection) in Vacutainer tubes without additives (BD, Mississauga, ON, Canada). The blood tubes were left overnight at $4^{\circ} \mathrm{C}$ to allow clotting before centrifugation $\left(1,900 \times g, 4^{\circ} \mathrm{C}, 15 \mathrm{~min}\right)$. Serum samples were then kept at $-20^{\circ} \mathrm{C}$ until determination of PRL and cortisol concentrations. Additional blood samples were collected in EDTA-coated Vacutainer tubes (BD) at $60,63,65$, and $67 \mathrm{~min}$ relative to the start of the first manual stimulation or injection. These tubes were immediately placed on ice and centrifuged $(1,900 \times g$, $4^{\circ} \mathrm{C}, 15 \mathrm{~min}$ ). The plasma samples were then stored at $-80^{\circ} \mathrm{C}$ until determination of ACTH. 


\section{Experiment 2}

Sixteen multiparous Holstein cows in mid-lactation $(162 \pm 9$ DIM) were used in a crossover experimental design. Cows were allocated to 1 of 2 groups (n $=8$ ) balanced according to parity, milk production, and DIM. The experiment consisted of 2 experimental periods of 1 wk separated by $1 \mathrm{wk}$ of rest. During the first experimental period, cows were treated $2 \mathrm{~h}$ after the morning milking as follows: (1) 4 cows received a s.c. injection of $0.5 \mathrm{~g}$ of domperidone $(10 \mathrm{~mL}$ of a 50 $\mathrm{g} / \mathrm{L}$ suspension of domperidone in canola oil; Equi-Tox Pharma Inc., Central, SC) on d 1 and 2 and an i.m. injection of $20 \mathrm{mg}$ of dexamethasone on d 1; (2) 4 cows received only a s.c. injection of $0.5 \mathrm{~g}$ of domperidone on $\mathrm{d} 1$ and 2 ; (3) 4 cows received a s.c. injection of canola oil $(10 \mathrm{~mL})$ on $\mathrm{d} 1$ and 2 and an i.m. injection of $20 \mathrm{mg}$ of dexamethasone on $\mathrm{d} \mathrm{1}$; and (4) 4 cows only received a s.c. injection of canola oil on $d 1$ and 2 . The same 4 treatments were repeated during the second experimental period, except that the cows that had been treated with dexamethasone during the first period did not receive it during the second period, and those that did not receive dexamethasone during the first period did receive it during the second period. The domperidone and canola oil treatments were not alternated. A summary of the treatment description is presented in Table 2.

Three days before the start of the treatments, a Silastic catheter (Dow Corning Corp.) was inserted into each cow's jugular vein. On d 1 and 2, blood samples were collected before, during, and after the morning milking (-20, -10, 0, 3, 5, 7, 10, 15, 20, 25, 30, 40, and 60 min relative to the start of milking) in Vacutainer tubes (BD) without additives. These blood samples were left at room temperature for approximately $2 \mathrm{~h}$ to allow clotting before centrifugation $\left(1,900 \times g, 4^{\circ} \mathrm{C}, 15\right.$ min). The serum samples were then kept at $-20^{\circ} \mathrm{C}$ until determination of PRL concentration.

On $\mathrm{d}-3,1,2,3,4,5$, and 7 of each experimental period, blood samples were collected from the coc- cygeal vein before the morning milking in Vacutainer tubes (BD) without additives. These blood samples were left at room temperature for $2 \mathrm{~h}$ to allow clotting before centrifugation $\left(1,900 \times g, 4^{\circ} \mathrm{C}, 15 \mathrm{~min}\right)$ and then stored at $-20^{\circ} \mathrm{C}$ until determination of serum PRL and cortisol concentrations. Additional blood samples were collected on the same days in EDTA-coated Vacutainer tubes (BD) and placed immediately on ice before centrifugation $\left(1,900 \times \mathrm{g}, 4^{\circ} \mathrm{C}, 15 \mathrm{~min}\right)$ and storage at $-80^{\circ} \mathrm{C}$ until determination of plasma IGF-1 concentration.

Milk production was recorded daily from $3 \mathrm{~d}$ before to $7 \mathrm{~d}$ after the start of the treatments for each experimental period. Milk samples $(50 \mathrm{~mL})$ were collected at the morning milking on $\mathrm{d}-3,1,2,3,4,5$, and 7 , centrifuged $\left(1,900 \times \mathrm{g}, 4^{\circ} \mathrm{C}, 15 \mathrm{~min}\right)$, skimmed, and stored at $-20^{\circ} \mathrm{C}$ until determination of milk PRL concentration. Additional milk samples were harvested on the same days for milk composition analysis. Milk fat, protein, and lactose concentrations were measured in a commercial laboratory (Valacta Inc., Sainte-Anne-deBellevue, QC, Canada).

\section{Sample Analyses}

We determined serum cortisol concentration by ELISA using the Cortisol Parameter Assay Kit (R\&D Systems Inc., Minneapolis, MN) following the manufacturer's recommendations (https://resources. rndsystems.com/pdfs/datasheets/kge008b.pdf)with a modification. Briefly, samples were centrifuged $\left(12^{\circ} \mathrm{C}, 5\right.$ $\min )$, and $100 \mu \mathrm{L}$ of the serum was diluted in $300 \mu \mathrm{L}$ of calibrator diluent before being added to a 96 -well goat anti-mouse microplate. The intra- and inter-assay coefficients of variation were $1.7 \%$ and $15.6 \%$, respectively. We measured serum and milk PRL concentrations by RIA as described by Bernier-Dodier et al. (2011). The intra- and inter-assay coefficients of variation were $4.8 \%$ and $8.9 \%$, respectively.

We measured plasma IGF-1 concentration by ELISA using the Human IGF-I Quantikine ELISA Kit (R\&D

Table 2. Summary of the treatments of experiment 2

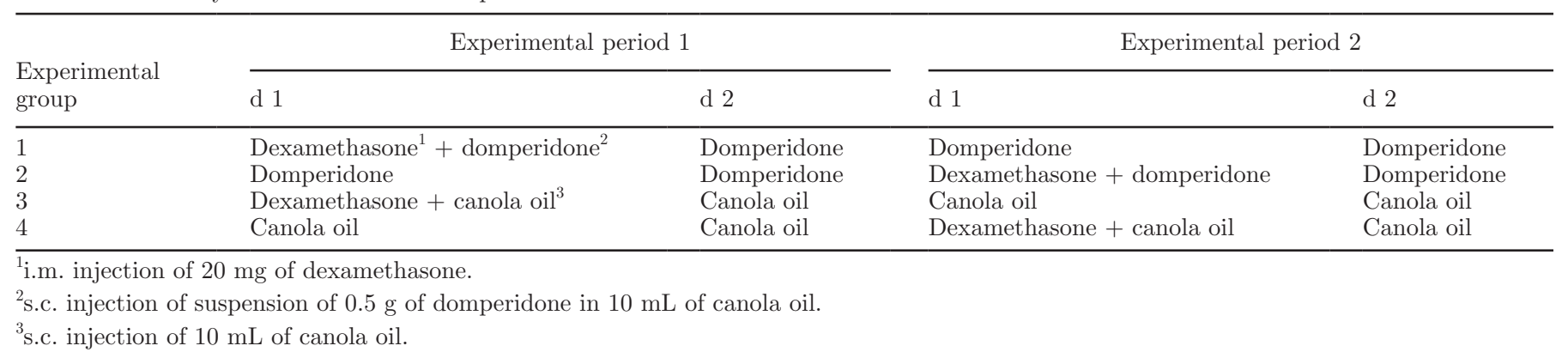


Systems) following the manufacturer's recommendations (https://resources.rndsystems.com/pdfs/datasheets/dg100.pdf) with some modifications. Briefly, plasma samples were pretreated by adding $360 \mu \mathrm{L}$ of pretreatment A solution to $40 \mu \mathrm{L}$ of the sample. After 10 min of incubation at room temperature, $50 \mu \mathrm{L}$ of the mixture was added to $200 \mu \mathrm{L}$ of pretreatment B solution. Then, $100 \mu \mathrm{L}$ of the pretreated plasma sample was diluted with $50 \mu \mathrm{L}$ of Assay Diluent RD1-53 (R\&D Systems Inc.). In a 96-well polystyrene microplate, 50 $\mu \mathrm{L}$ of the plasma sample was mixed with $150 \mu \mathrm{L}$ of Assay Diluent RD1-53 and incubated at $4^{\circ} \mathrm{C}$ for $2 \mathrm{~h}$. After being washed and incubated at $4^{\circ} \mathrm{C}$ for $1 \mathrm{~h}$ with $200 \mu \mathrm{L}$ of unlabeled IGF-1 conjugate, the wells were washed and incubated with $200 \mu \mathrm{L}$ of substrate solution at room temperature for $30 \mathrm{~min}$. The reaction was stopped by adding $2 \mathrm{~N}$ sulfuric acid, and optical density was read at $450 \mathrm{~nm}$ using a SpectraMax 250 microplate reader. The intra- and inter-assay coefficients of variation were and $5.2 \%$ and $4.1 \%$, respectively.

Plasma ACTH concentration was determined by ELISA using the Bovine Adrenocorticotropic Hormone ELISA Kit (Cusabio, Wuhan, China) following the manufacturer's recommendations. The optical density was read at $450 \mathrm{~nm}$ using a SpectraMax 250 microplate reader (Molecular Devices, Sunnydale, CA). The intraand inter-assay coefficients of variation were and 7.4 and $18.4 \%$, respectively.

\section{Statistical Analysis}

For Experiment 1, we calculated the amounts of PRL and cortisol released into blood during manual stimulation by determining area under the curve. We also calculated basal and peak concentrations. We analyzed data as Latin squares by ANOVA using the MIXED procedure of SAS (SAS Institute Inc., Cary, NC). The model includes the effects of treatments, sampling days, and cows. For experiment 2, we analyzed daily data by ANOVA using the MIXED procedure of SAS (SAS Institute Inc.). We used time as a repeated effect, and cow(treatment) as the subject. Data were considered statistically significant when $P<0.05$. We also calculated the basal and peak concentrations of PRL and the amount of PRL released during milking (corresponding to the areas under the curves).

\section{RESULTS}

\section{Experiment 1}

During the first phase of the sampling period $(-20$ to $60 \mathrm{~min}$ ), basal PRL concentration was similar among all treatments $(P>0.1$; Figure $1 \mathrm{~A})$. As expected, the first mammary gland stimulation (STIM and METY) induced a surge in PRL release $(P<0.01)$. The amount of PRL (area under the curve) and peak PRL concentration during stimulation were similar in both treatments. In the treatments where the mammary gland was not stimulated in the first phase (CTL and DEXA), we observed no significant release of PRL. During the second phase of the sampling period (60 to $120 \mathrm{~min}$ ), the peak concentration of PRL was lower $(P=0.03)$ and the total amount of PRL released during stimulation tended to be lower $(P=0.09)$ in cows that had been stimulated during the first phase (STIM and METY; Figure 1A and Table 3). The PRL release induced by the second mammary gland stimulation was not affected by dexamethasone or metyrapone (Table $1)$.

During the first phase of the sampling period, basal cortisol concentration was similar among all treatments $(P>0.1$; Figure 1B). As with PRL, the first mammary gland stimulation (STIM and METY) induced a surge in cortisol release $(P<0.01)$, but we observed no significant release of cortisol in the treatments where the mammary gland was not stimulated manually (CTL and DEXA). Metyrapone did not significantly affect the peak concentration or total amount of cortisol released but did tend $(P=0.09)$ to decrease the amount of cortisol released above the basal level compared with STIM. During the second phase of the sampling period, dexamethasone decreased the peak concentration $(P=0.01)$ and the amount of cortisol released during mammary gland stimulation $(P<0.01$; Table 3$)$. Mammary gland stimulation in the first period reduced the amount of cortisol released in the second period in the STIM treatment $(P=0.04)$, but not in the METY treatment.

We observed no change in plasma ACTH concentration in response to manual stimulation in the second sampling period (Supplementary Figure S1; https:// doi.org/10.3168/jds.2016-11490).

\section{Experiment 2}

Milk Yield and Composition. Before the start of treatments, milk production was similar among the treatment groups (Figure 2). We observed a dexamethasone $\times$ day interaction $(P<0.001)$ during the treatment period. Milk production was reduced in the dexamethasone-treated cows $(P<0.001)$ during the 2 $\mathrm{d}$ that followed injection. However, domperidone did not affect milk yield, regardless of whether the cows were injected with dexamethasone or not.

Milk fat content was similar among the treatment groups before the start of the treatments (Supplementary Figure S2A; https://doi.org/10.3168/jds.2016- 
11490). We observed a dexamethasone $\times$ day interaction $(P<0.001)$ during the treatment period. Milk fat percentage was greater $(P<0.05)$ in the dexamethasone-treated cows in the $3 \mathrm{~d}$ that followed injection.
Domperidone did not affect milk fat response to dexamethasone (dexamethasone $\times$ domperidone, $P=0.4$ ) but tended to increase milk fat percentage $(P=0.07)$. Milk fat yield was similar among the treatment groups
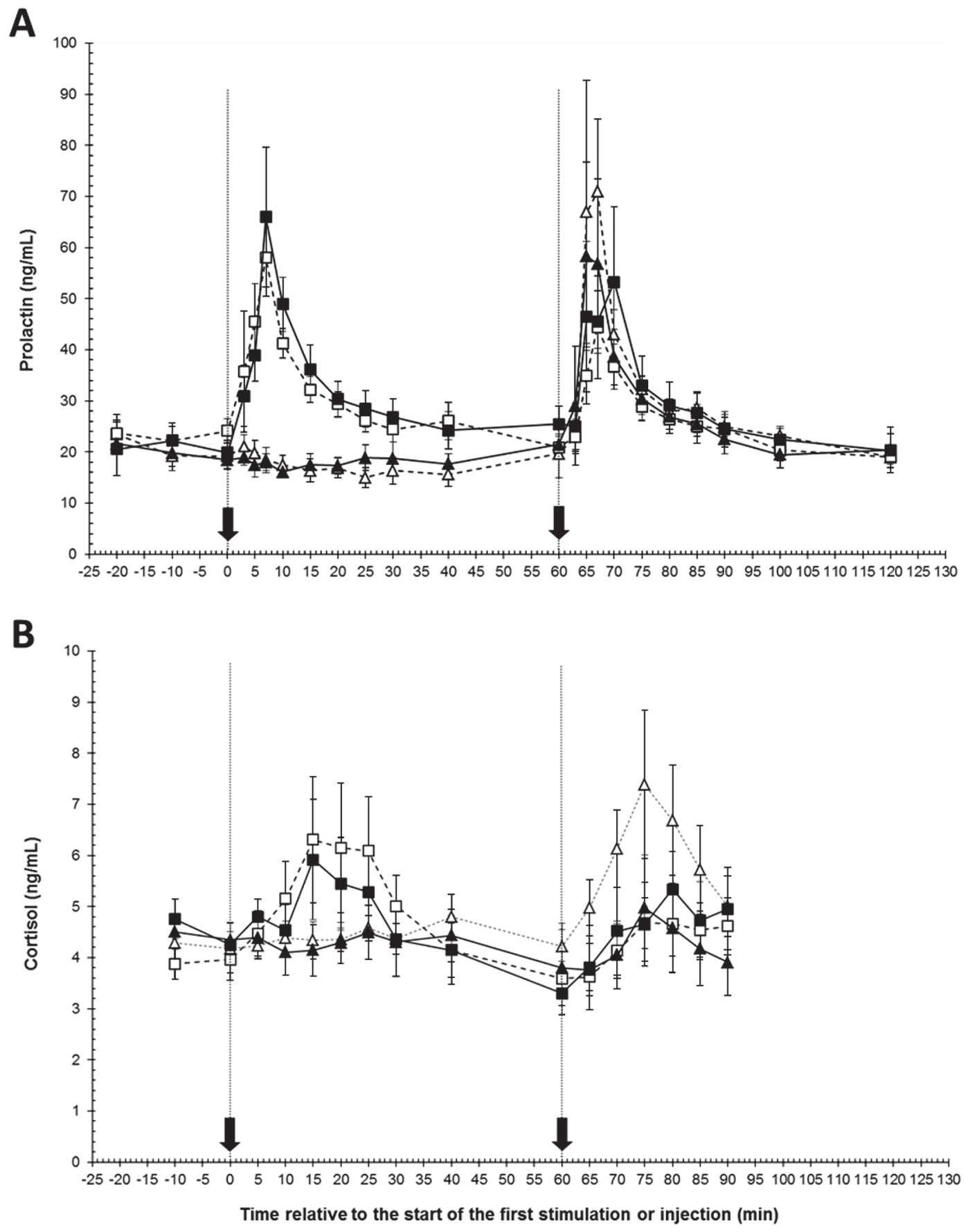

Figure 1. Serum prolactin (A) and cortisol (B) concentrations. Four hours after the morning milking, the cows $(\mathrm{n}=8)$ received 1 of the following treatments: (1) a 5-min manual stimulation of the mammary gland (STIM, white squares, dashed line); (2) an i.v. injection of 1 mg of dexamethasone (DEXA, black triangles, solid line); (3) infusions of $2.5 \mathrm{~g}$ of metyrapone in the omasum 4 and $2 \mathrm{~h}$ before a 5-min manual stimulation of the mammary gland (METY, black squares, solid line); or (4) no treatment (CTL, white triangles, dashed line). Sixty minutes later, the mammary gland of each cow was stimulated for $5 \mathrm{~min}$. The times of administration of the treatments or manual stimulations are represented by black arrows. Data are presented as arithmetic means \pm SEM. 


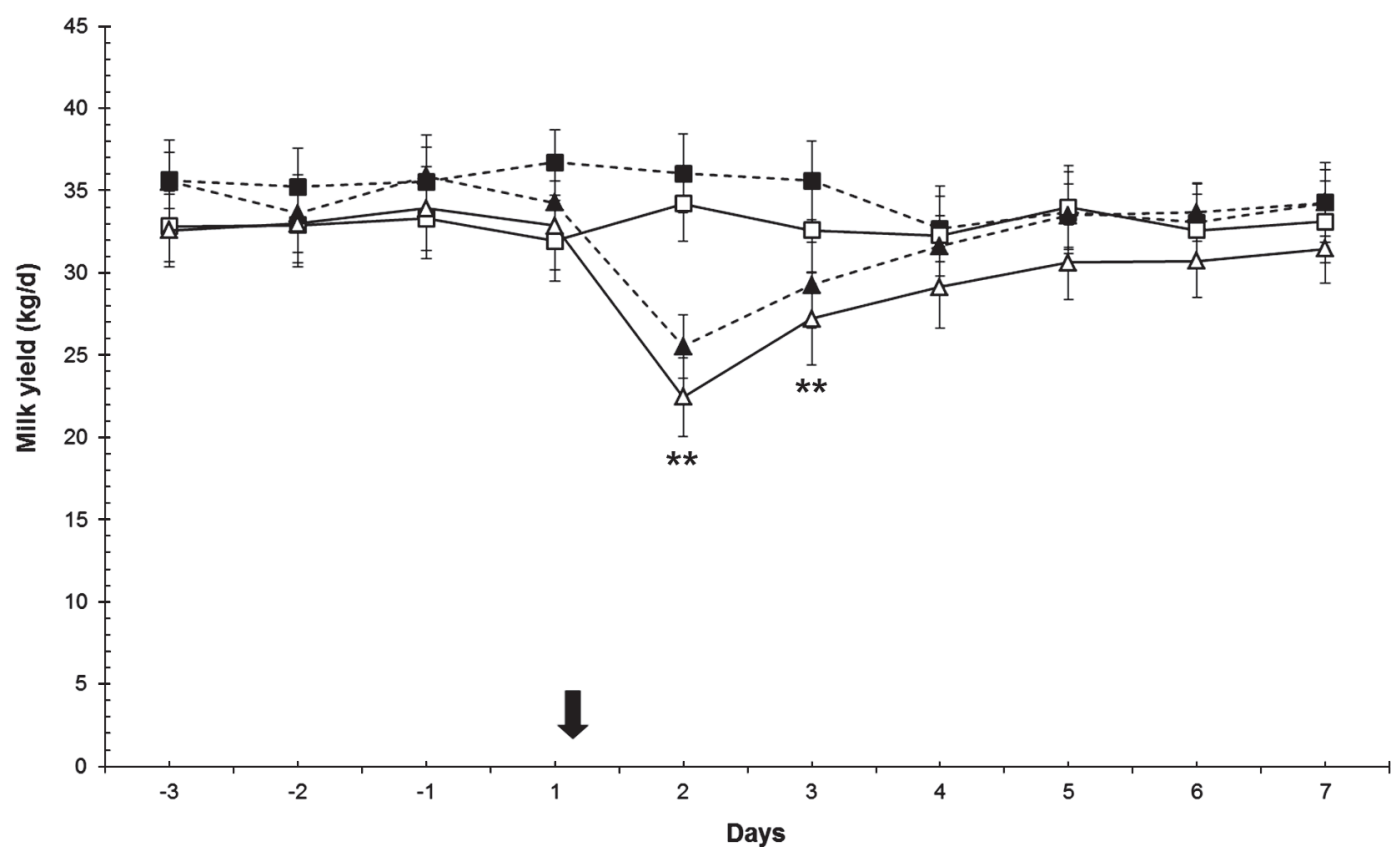

Figure 2. Milk production of cows injected with $0.5 \mathrm{~g}$ of domperidone on d 1 and 2 and with $20 \mathrm{mg}$ of dexamethasone on d 1 (black triangles, dashed line); injected with domperidone on d 1 and 2 (black squares, dashed line); injected with canola oil on d 1 and 2 and with dexamethasone on $\mathrm{d} 1$ (white triangles, solid line); or injected with canola oil on d 1 and 2 (white squares, solid line). The time of the first injection is represented by the black arrow. Data are presented as LSM \pm SEM. The significant differences between the dexamethasone-treated and nontreated cows are indicated as follows: ${ }^{* *} P<0.01$.

in the pretreatment period and was not affected by dexamethasone injection during the treatment period (data not shown). Domperidone injection significantly increased milk fat yield $(P=0.035)$, which was greater on $\mathrm{d} 4$ and $5(P<0.05)$ in the domperidone-treated cows than in the oil-treated cows.

Milk protein content was similar among the treatment groups before the start of the treatments
(Supplementary Figure S2B; https://doi.org/10.3168/ jds.2016-11490). We observed a dexamethasone $\times$ day interaction $(P<0.001)$ during the treatment period. Milk protein percentage was greater $(P<0.05)$ in the dexamethasone-treated cows in the $2 \mathrm{~d}$ that followed injection. Domperidone did not affect milk protein response to dexamethasone (dexamethasone $\times$ domperidone, $P=0.98$ ) or milk protein percentage. Milk

Table 3. Effect of a 5-min manual mammary gland stimulation on milking-induced prolactin and cortisol release; 60 min before this stimulation, the cows received 1 of 4 treatments ${ }^{1}$

\begin{tabular}{|c|c|c|c|c|c|c|c|c|}
\hline Item $^{2}$ & \multicolumn{4}{|c|}{ Treatment } & SEM & \multicolumn{3}{|c|}{$P$-value } \\
\hline \multicolumn{9}{|l|}{ Prolactin } \\
\hline Baseline $(\mathrm{ng} / \mathrm{mL})$ & 24.5 & 19.6 & 20.9 & 21.4 & 3.2 & 0.44 & 0.70 & 0.51 \\
\hline Peak $(\mathrm{ng} / \mathrm{mL})$ & 59.1 & 94.1 & 51.1 & 77.9 & 12.7 & 0.66 & 0.38 & 0.026 \\
\hline $\operatorname{AUC}(\mathrm{ng} \cdot \min / \mathrm{mL})$ & 1,191 & 1,317 & 1,104 & 1,198 & 129.6 & 0.64 & 0.52 & 0.41 \\
\hline Baseline (ng/mL) & 3.9 & 4.5 & 4.3 & 4.2 & 0.3 & 0.40 & 0.52 & 0.40 \\
\hline Peak (ng/mL) & 6.2 & 7.9 & 5.8 & 5.2 & 0.7 & 0.70 & 0.01 & 0.41 \\
\hline $\operatorname{AUC}(\mathrm{ng} \cdot \min / \mathrm{mL})$ & 139.6 & 177.6 & 128.7 & 127 & 11.6 & 0.52 & 0.006 & 0.14 \\
\hline $\operatorname{RELA}(\mathrm{ng} \cdot \mathrm{min} / \mathrm{mL})$ & 4.8 & 50.4 & 11.1 & -5.8 & 11.3 & 0.70 & 0.003 & 0.22 \\
\hline
\end{tabular}

${ }^{1}$ Treatments: STIM = a 5-min manual stimulation of the mammary gland $4 \mathrm{~h}$ after the morning milking; DEXA = an i.v. injection of 1 mg of dexamethasone $4 \mathrm{~h}$ after the morning milking; METY = infusions of $2.5 \mathrm{~g}$ of metyrapone in the omasum 4 and $2 \mathrm{~h}$ before a 5 -min manual stimulation of the mammary gland; and CTL $=$ no treatment $4 \mathrm{~h}$ after the morning milking. Data are presented as LSM.

${ }^{2} \mathrm{AUC}=$ area under the curve; RELA $=$ AUC minus the baseline of prolactin or cortisol concentration. 
protein yield was similar among the treatment groups in the pretreatment period (data not shown). We observed a dexamethasone $\times$ domperidone $\times$ day interaction $(P<0.01)$. Dexamethasone injection decreased milk protein yield $(P<0.05)$ on only the following day in the domperidone-treated cows and on the 2 following days in the oil-treated cows. Domperidone injection did not affect milk protein yield.

Milk lactose content was similar among the treatment groups before the start of the treatments (Supplementary Figure S2C; https://doi.org/10.3168/jds.2016$11490)$. We observed a dexamethasone $\times$ day interaction $(P<0.01)$ during the treatment period. Milk lactose content was lower $(P<0.01)$ in the dexamethasonetreated cows on d 2, 4, and 5. Domperidone did not affect milk lactose response to dexamethasone (dexamethasone $\times$ domperidone, $P=0.6$ ) or milk lactose percentage. Milk lactose yield was similar among the treatment groups in the pretreatment period (data not shown). We observed a dexamethasone $x$ day interaction $(P<0.001)$ on lactose yield during the treatment period. Milk lactose yield was lower $(P<0.05)$ in the dexamethasone-treated cows from d 2 to 4 and tended to be lower $(P=0.08)$ on $\mathrm{d} 5$. Domperidone did not affect lactose yield.

Prolactin, Cortisol, and IGF-1 Concentrations. We observed an interaction between domperidone and experimental period $(P=0.03)$ for serum PRL concentration. In the first period, domperidone induced a gradual increase (domperidone $\times$ day, $P=0.05$; Figure $3 \mathrm{~A})$ in serum PRL, which was greater $(P<0.05)$ in the domperidone-treated cows than in the oil-injected cows on d $3,4,5$, and 7 . We also observed a carryover effect of domperidone from the first experimental period to the second. The serum PRL concentration in the domperidone-treated cows during the first experimental period was still greater than that of the oil-treated cows before the start of the second period $(P<0.001$; Figure $3 \mathrm{~B})$. Serum PRL concentration remained elevated in the domperidone-treated cows during the second treatment period $(P<0.01)$. We observed a dexamethasone $\times$ day interaction $(P<0.01)$ during both treatment periods. In comparison with the non-dexamethasonetreated cows, serum PRL concentration was lower $(P$ $<0.001)$ in the dexamethasone-treated cows on $\mathrm{d} 2$ (Figure 3A and B).

As with serum PRL concentration, we observed an interaction between domperidone and experimental period $(P=0.04)$ for milk PRL concentration. In the first period, domperidone induced a gradual increase (domperidone $\times$ day, $P=0.03$; Figure $4 \mathrm{~A})$ in milk PRL concentration, which was greater $(P<0.01)$ in the domperidone-treated cows than in the oil-injected cows from d 3 to 7 . We observed a carryover effect of domperidone from the first experimental period to the second. The milk PRL concentration of the domperidone-treated cows during the first experimental period was still greater than that of the oil-treated cows before the start of the second period $(P<0.01$; Figure $4 \mathrm{~B})$. Milk PRL concentration remained greater in the domperidone-treated cows during the second treatment period $(P<0.03)$. We observed a dexamethasone $\times$ day interaction $(P<0.001)$ during both treatment periods. In comparison with the non-dexamethasonetreated cows, milk PRL was lower $(P<0.001)$ in the dexamethasone-treated cows on d 2 but was greater $(P<0.03)$ from $\mathrm{d} 4$ to 7 during the first period, and milk PRL concentration was lower $(P<0.001)$ in the dexamethasone-treated cows on d 2 but was greater $(P$ $=0.03$ ) on $\mathrm{d} 5$ during the second period (Figure $4 \mathrm{~A}$ and $\mathrm{B})$.

We collected blood samples around the time of the morning milking before and after the start of treatments in the cows treated with dexamethasone. As with daily PRL concentration, we observed significant $(P<0.03)$ interactions between experimental period and domperidone on milking-induced parameters. During the first experimental period, domperidone did not affect basal and peak PRL concentrations or the total amount of PRL released (Figure 5A). However, on the day following dexamethasone injection, basal PRL concentration $(P=0.02)$ and total amount of PRL released $(P<0.01)$ were reduced, and peak PRL concentration tended to be reduced $(P=0.1)$. During the second experimental period, domperidone increased $(P=0.01)$ basal PRL concentration and tended $(P$ $=0.06)$ to increase the total amount of PRL released (Figure 5B). As for the first experimental period, dexamethasone reduced basal PRL concentration $(P=$ $0.02)$, peak PRL concentration $(P=0.02)$, and total amount of PRL released $(P<0.03)$.

Serum cortisol concentration was similar among the treatment groups before the start of the treatments (Figure 6A). We observed a significant interaction between dexamethasone and day of sampling $(P=0.01)$ during the treatment period. In comparison with the non-dexamethasone-treated cows, cortisol concentrations were lower $(P \leq 0.05)$ on $\mathrm{d} 2,3,4$, and 5 in the dexamethasone-treated cows. Domperidone did not affect serum cortisol concentration.

The plasma concentration of IGF-1 was similar among the treatment groups before the start of the treatments (Figure 6B). We observed a significant interaction between dexamethasone and day of sampling $(P<0.001)$ during the treatment period. Plasma IGF1 concentration in the dexamethasone-treated cows was 
lower on $\mathrm{d} 2$ and $3(P<0.04)$ but was greater on $\mathrm{d} 4$ $(P=0.03)$ and tended to be greater on d $5(P=0.06)$ than in the non-injected cows. Domperidone did not affect plasma IGF-1 concentration.

\section{DISCUSSION}

The aim of experiment 1 was to test whether glucocorticoids are responsible for the decrease in PRL re-
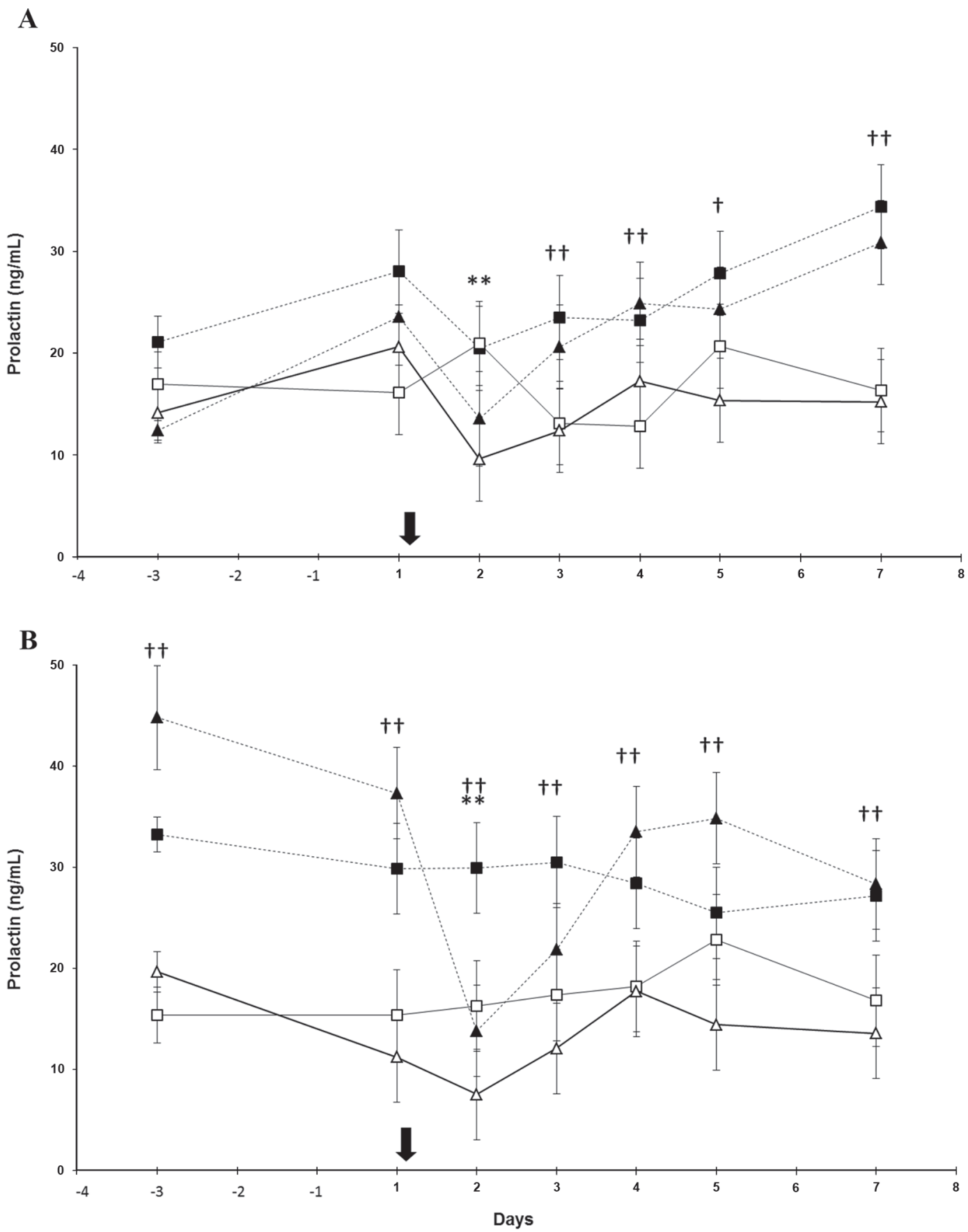

Figure 3. Prolactin concentration measured in the serum of cows injected with $0.5 \mathrm{mg}$ of domperidone on $\mathrm{d} 1$ and 2 and with $20 \mathrm{mg}$ of dexamethasone on d 1 (black triangles, dashed line); injected with domperidone on d 1 and 2 (black squares, dashed line); injected with canola oil on d 1 and 2 and with dexamethasone on d 1 (white triangles, solid line); or injected with canola oil on d 1 and 2 (white squares, solid line) during the first experimental period (A) and the second experimental period (B). The time of the first injection is represented by the black arrow. Data are presented as LSM \pm SEM. The significant differences between the dexamethasone-treated and nontreated cows are indicated as follows: ${ }^{* *} P<0.01$. The significant differences between the domperidone-treated cows and the oil-treated cows are indicated as follows: $\dagger P<$ $0.05, \dagger+P<0.01$. 


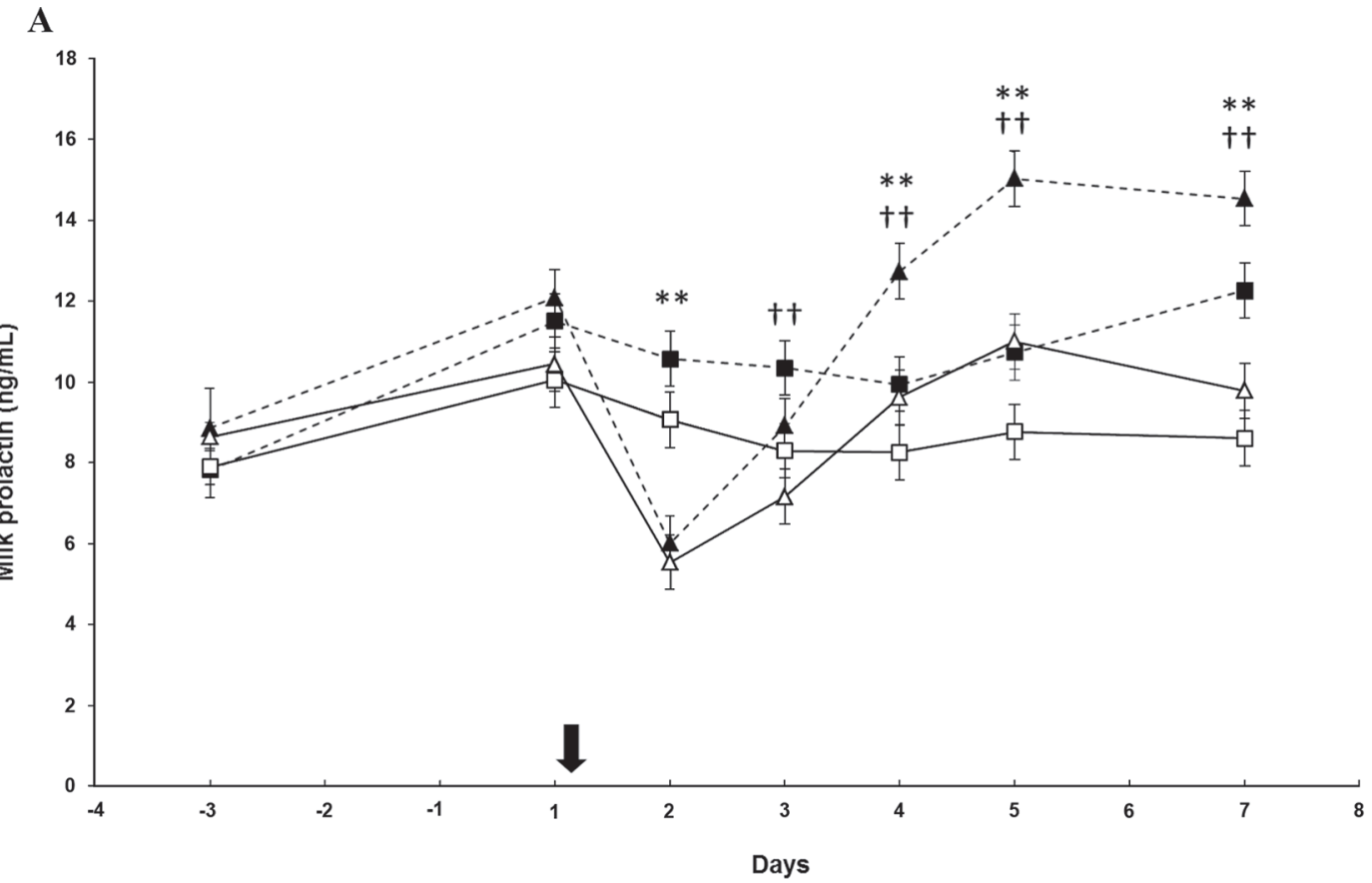

B

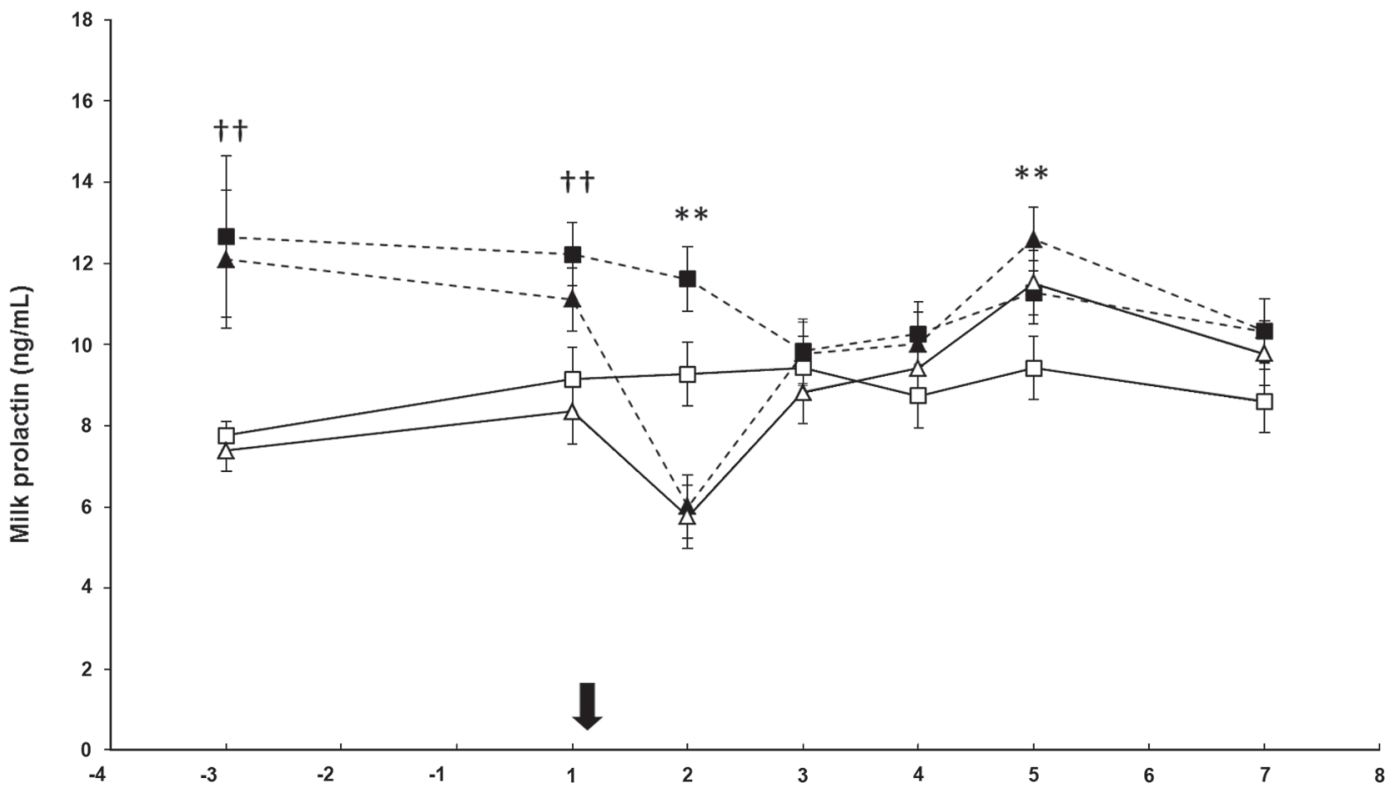

Figure 4. Prolactin concentration measured in the milk of cows injected with $0.5 \mathrm{mg}$ of domperidone on $\mathrm{d} 1$ and 2 and with $20 \mathrm{mg}$ of dexamethasone on d 1 (black triangles, dashed line); injected with domperidone on d 1 and 2 (black squares, dashed line), injected with canola oil on d 1 and 2 and with dexamethasone on d 1 (white triangles, solid line), or injected with canola oil on d 1 and 2 (white squares, solid line) during the first experimental period (A) and the second experimental period (B). The time of the first injection is represented by the black arrow. Data are presented as LSM \pm SEM. The significant differences between the dexamethasone-treated and nontreated cows are indicated as follows: $* * P$ $<0.01$. The significant differences between the domperidone-treated cows and the oil-treated cows are indicated as follows: $\dagger \dagger P<0.01$.

lease associated with multiple mammary stimulations. Peak PRL concentration and the total amount of PRL released were decreased during the second mammary gland stimulation, occurring 1 hour after the first. This result was in accordance with previous results showing that the amount of PRL released at milking decreased as the number of mammary gland stimulations increased (Lacasse and Ollier, 2014). However, this inhibition could not be reproduced by an injection of $1 \mathrm{mg}$ of dexamethasone. Therefore, under our experimental 
conditions, the reduction in PRL concentration caused by multiple stimulations of the mammary gland did not seem to be due to milking-induced glucocorticoid release.
A previous mammary gland stimulation reduced the amount of cortisol released during a second stimulation in the STIM treatment but not in the METY treatment. A previous study in calves found that adminis-

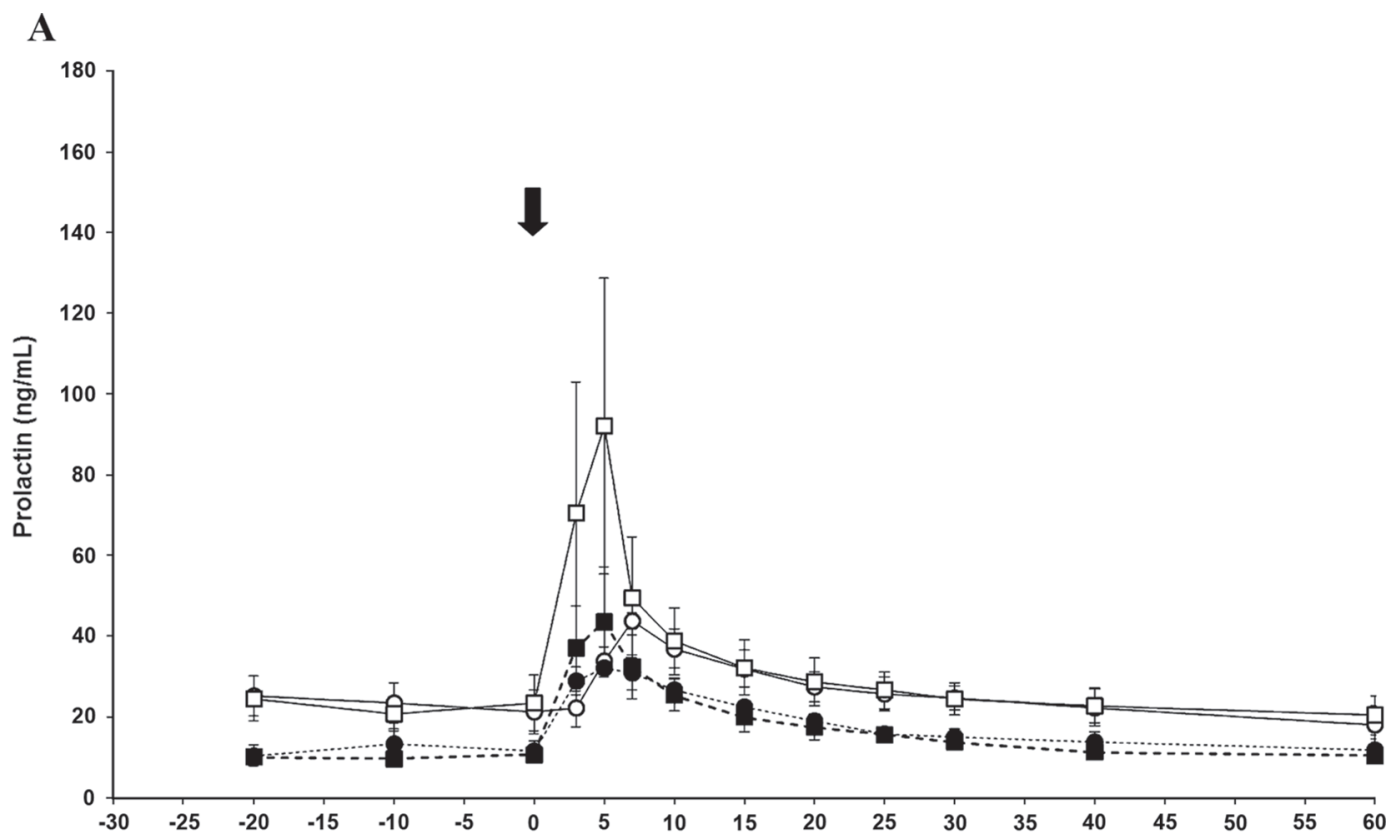

B

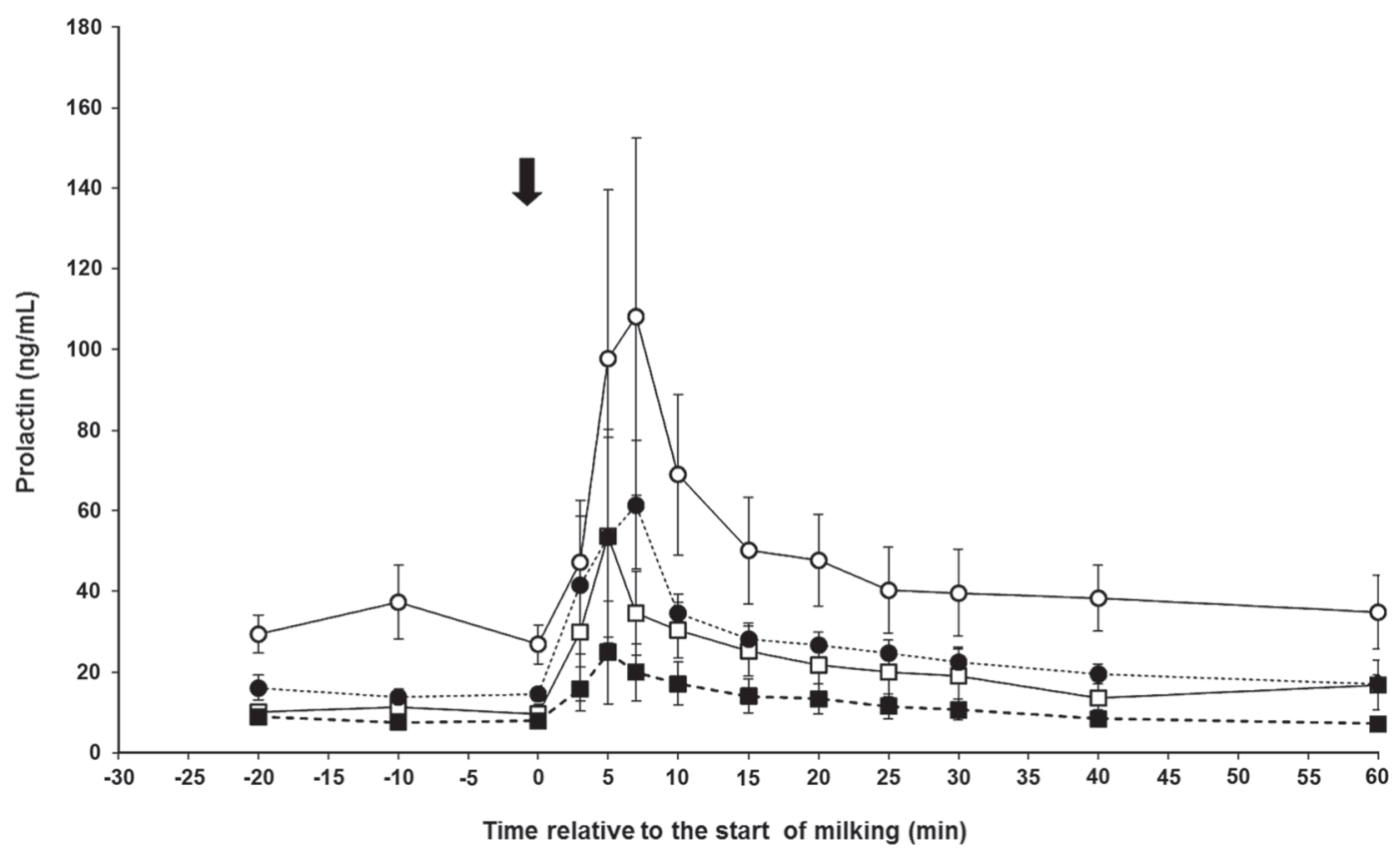

Figure 5. Serum concentrations of prolactin released during d 1 (before injection) and d 2 milkings in cows injected on d 1 with 20 mg of dexamethasone and on $\mathrm{d} 1$ and 2 with domperidone (white circles, solid line, for $\mathrm{d} 1$ and black circles, dashed line, for d 2 milkings, respectively) or canola oil (white squares, solid line, for $\mathrm{d} 1$ and black squares, dashed line, for d 2 milkings, respectively) during the first experimental period (A) and the second experimental period (B). The start of milking is represented by the black arrow. Data are presented as arithmetic means \pm SEM. 
$\mathbf{A}$

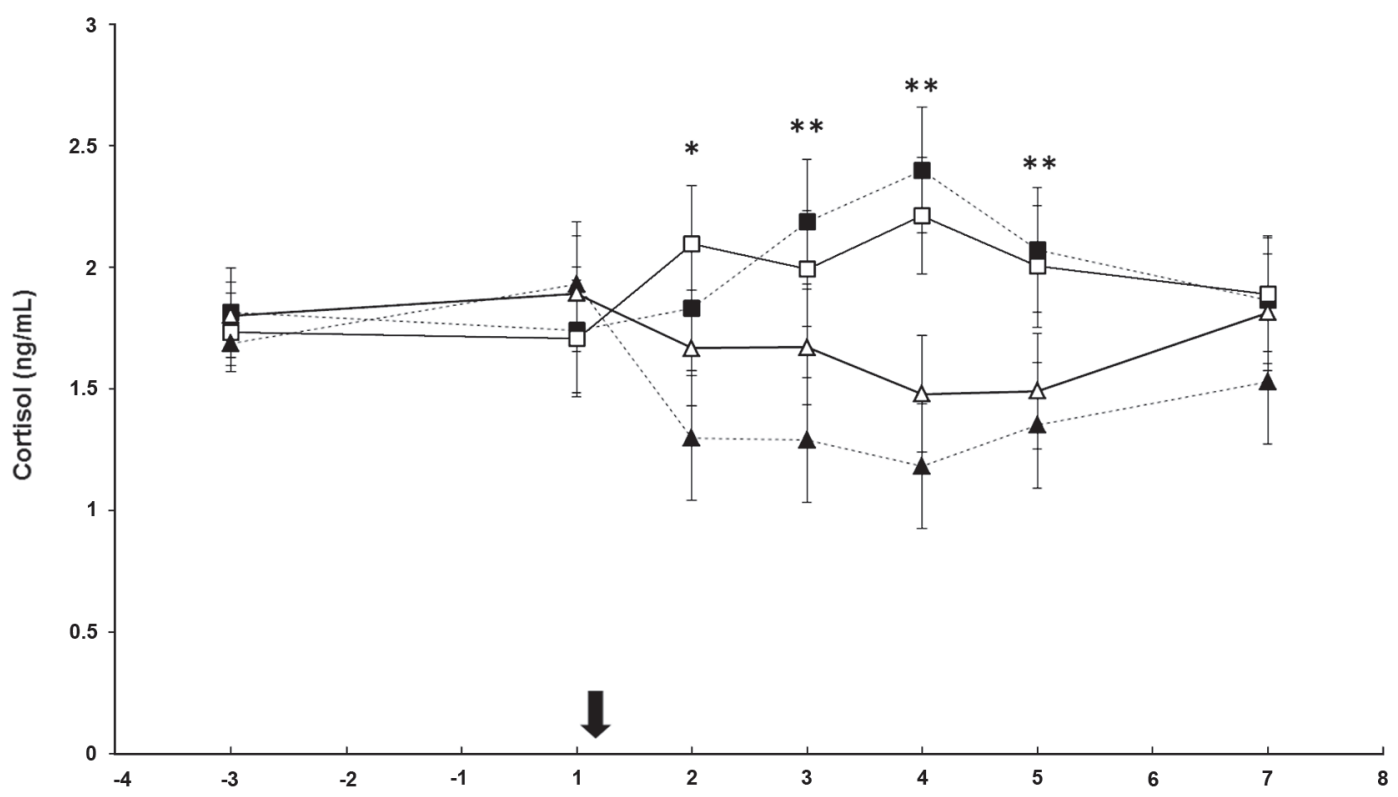

B

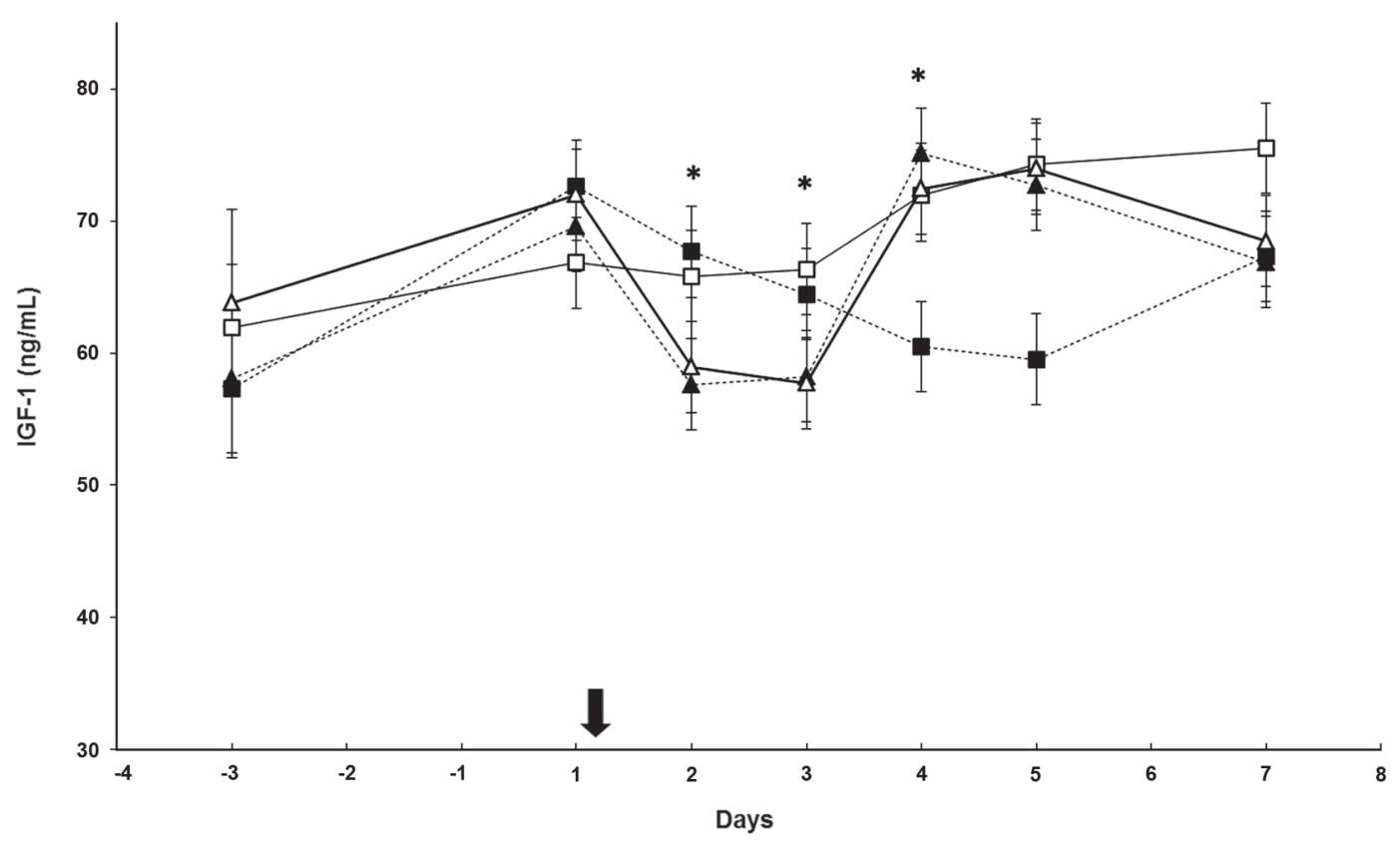

Figure 6. Basal serum cortisol (A) and plasma IGF-1 (B) concentrations of cows injected with domperidone on d 1 and 2 and with 20 mg of dexamethasone on d 1 (black triangles, dashed line), injected with domperidone on d 1 and 2 (black squares, dashed line), injected with canola oil on d 1 and 2 and with dexamethasone on d 1 (white triangles, solid line), or injected with canola oil on d 1 and 2 (white squares, solid line). The time of the first injection is represented by the black arrow. Data are presented as LSM \pm SEM. The significant differences between the dexamethasone-treated and nontreated cows are indicated as follows: ${ }^{*} P<0.05,{ }^{* *} P<0.01$.

tering $750 \mathrm{mg}$ of metyrapone orally 6 times every $4 \mathrm{~h}$, for a total dose of $4.5 \mathrm{~g}$, reduced the increase in cortisol release induced by transport stress without suppressing the release (Agnes et al., 1990). In another study in calves, the oral administration of $3 \mathrm{~g}$ of metyrapone every $4 \mathrm{~h}$ for $48 \mathrm{~h}$ decreased the cortisol surge due to castration without suppressing it (Fisher et al., 1997). In the present study, $5 \mathrm{~g}$ of metyrapone was infused into the omasum to avoid ruminal degradation. Despite this method, the dose was probably not large enough to 
significantly depress basal cortisol levels. Nevertheless, the amount of cortisol released in response to the first manual stimulation was numerically reduced, and that result probably explains why cortisol release during the second stimulation was not significantly reduced in the metyrapone-treated cows.

Dexamethasone induced a decrease in the amount of cortisol released during mammary gland stimulation. This inhibitory effect of dexamethasone on cortisol release has been reported in humans (Weiner, 1989; Koopmans et al., 1992; Huizenga et al., 1998), dogs (Pessina et al., 2009), horses (Soma et al., 2005; Abraham et al., 2009), and cattle (Toutain et al., 1982). Dexamethasone inhibits cortisol concentration because glucocorticoids exert negative regulatory feedback on the hypothalamo-pituitary-adrenal axis by inhibiting ACTH secretion (Keller-Wood and Dallman, 1984; Feldman and Weidenfeld, 1995). In response to injection of the synthetic glucocorticoid into the bloodstream, the synthesis and release of cortisol by the adrenal glands were therefore downregulated. Although ACTH concentration in plasma was not affected by the treatments, a decrease in ACTH release cannot be ruled out, given that measurements were taken at only a few time points after the second manual stimulation of the mammary gland. A previous study also showed that the intramuscular administration of dexamethasone in bovines suppressed the response of the adrenal cortex to ACTH (Toutain et al., 1982). Therefore, it is possible that dexamethasone injections inhibited cortisol synthesis by decreasing the sensitivity of the adrenal gland to ACTH.

The effects of glucocorticoids on PRL release were different between the 2 experiments. In experiment 1 , a dose of $1 \mathrm{mg}$ of dexamethasone administered 60 min before blood sampling did not affect the amount of PRL released during mammary gland stimulation. A previous study showed that in cattle, 2 to $3 \mathrm{~h}$ was necessary before the repressor effect of dexamethasone on cortisol release could be observed (Toutain et al., 1982). In contrast, in experiment 2, a dose of $20 \mathrm{mg}$ of dexamethasone was sufficient to cause a reduction in basal serum and milk PRL concentrations on the day after the injection and to decrease the peak PRL concentration and total amount of PRL released during milking. The dose of glucocorticoids used $(1 \mathrm{mg})$ in experiment 1, the time of injection relative to the time of sampling (60 min), or both may have been insufficient to allow us to detect any potential effect of dexamethasone on the PRL release induced by mammary gland stimulation. Nevertheless, the inhibitory effect of dexamethasone on basal and milking-induced PRL secretions was consistent with the findings of previous rodent studies. In lactating rats, dexamethasone treat- ment inhibited the PRL release induced by the suckling stimulus (Vilela and Giusti-Paiva, 2011), and Horváth et al. (2001) reported that PRL release following domperidone injection was reduced by dexamethasone treatment and enhanced by adrenalectomy in rats. It is therefore tempting to state that glucocorticoids inhibit PRL synthesis, PRL secretion, or both.

The main physiological control of PRL secretion is exerted by the inhibitory action of dopamine on the lactotrophs of the anterior pituitary via dopamine D2 receptors (La Torre and Falorni, 2007). Domperidone is a dopamine antagonist that enhances PRL release by preventing the inhibitory action of dopamine secreted in the hypothalamus by the tuberoinfundibular neurons. Our results did show that PRL concentrations in both serum and milk gradually increased in the cows treated with domperidone compared with the cows treated with oil. The fact that dexamethasone inhibited PRL levels in the domperidone-treated cows suggests that the inhibitory action of glucocorticoids is not mediated through enhanced secretion of dopamine by the hypothalamus. As stated above, dexamethasone exerts its inhibitory action on cortisol and through the inhibition of ACTH release by the pituitary gland (Miller et al., 1992; Feldman and Weidenfeld, 1995; de Kloet et al., 1998). It is therefore possible that dexamethasone targeted the pituitary gland and affected the release of PRL by lactotrophs. This possibility is supported by the results of a previous experiment in rats: the release of immunoreactive PRL from the pituitary gland was significantly reduced by dexamethasone (Taylor et al., 1995). The mechanism of such an inhibition has not yet been explained, but it does not involve a dopaminergic component. Glucocorticoids are known to bind and activate the glucocorticoid receptor, which will target and modulate the expression of certain genes (Burnstein and Cidlowski, 1992). Low doses of corticosterone decreased PRL mRNA expression in vitro, whereas high doses of corticosterone enhanced it (Yokoyama et al., 2008). Thus, at a certain concentration, glucocorticoids may reduce the expression of PRL by the lactotrophs of the pituitary gland.

In the present study, dexamethasone reduced milk yield for $2 \mathrm{~d}$. Other studies have already reported that i.m. injections of dexamethasone depressed milk yield in cows (Hartmann and Kronfeld, 1973; Shamay et al., 2000). Moreover, dexamethasone decreased milk lactose percentage and milk lactose yield. It has been suggested that glucocorticoids alter the glucose partitioning between the mammary gland and other organs by disadvantaging the udder (Hartmann and Kronfeld, 1973). A recent study reported that dexamethasone induced transient hyperglycemia in cows (Ollier et al., 2016), which suggests that glucocorticoids decrease glu- 
cose uptake by the mammary gland. Although no study has reported the effect of glucocorticoids on mammary gland glucose uptake, glucocorticoids decrease glucose uptake in skeletal muscle and adipose tissue by causing a state of insulin resistance (Kuo et al., 2015). A reduction of glucose uptake would lead to a decrease in lactose synthesis. Given that lactose is the major osmotic component of milk, a reduction in glucose mammary uptake is likely involved in the depression of milk production due to dexamethasone administration.

In contrast, despite the induction of an increase in serum and milk PRL concentrations, domperidone did not affect milk production. In an earlier study, cows injected daily with $0.3 \mathrm{~g}$ of domperidone for $5 \mathrm{wk}$ displayed higher serum and milk PRL concentrations from d 6 to d 28 and produced more milk during wk 3 and 4 of treatment compared with control cows (Lacasse and Ollier, 2015). Therefore, it seems there is a delay between an increase in PRL secretion and the enhancement of milk production. The shorter duration of treatment ( $2 \mathrm{~d}$ vs. $5 \mathrm{wk}$ ) may explain the absence of effect of domperidone on milk production in the present study.

Given that most recent studies highlight a galactopoietic role for PRL (Lacasse et al., 2016), the fact that dexamethasone depressed both basal PRL concentration and milking-induced PRL release could have contributed to the decrease in milk production. Conversely, domperidone induced an increase in basal serum and milk PRL concentrations from $2 \mathrm{~d}$ after injection. However, this stimulation of PRL secretion could not prevent the dexamethasone-induced inhibition of milk production, although PRL was transiently depressed by dexamethasone in these cows. A previous study reported that the inhibition of PRL secretion depressed milk production, and that this effect was associated with a decrease in milk lactose concentration (Lacasse et al., 2011). In the present study, the reduction in milk production induced by dexamethasone also caused a depression in milk lactose concentration. Therefore, PRL inhibition may contribute to the glucocorticoid inhibition of milk production. A decrease in mammary tissue sensitivity to PRL induced indirectly by dexamethasone also cannot be completely excluded. For instance, glucocorticoids have been shown to modulate the number of PRL receptors on the mammary cells of lactating mice (Sakai and Banerjee, 1979). In addition, glucocorticoids have been reported to modulate hormone effects by interacting with transcription factors in the mammary epithelial cells (Groner, 2002). A decrease in mammary cell sensitivity to PRL could explain the negative effect of dexamethasone on milk yield, even in the presence of domperidone. However, the design of the present experiment did not allow us to determine whether PRL sensitivity was affected.
In the present study, serum IGF-1 concentration was decreased during the $2 \mathrm{~d}$ following the injection of dexamethasone, consistent with previous studies (Maciel et al., 2001). This effect could come from the inhibitory role exerted by dexamethasone on PRL release. Indeed, it has been suggested that PRL helps maintain IGF-1 levels by repressing the inhibitory action of IGFbinding protein 5 on IGF-1 (Flint and Knight, 1997). However, Lacasse et al. (2011) did not observe any effect of PRL inhibition on IGF-1 concentration. Still, a previous study showed that IGF-1 can stimulate milk production in lactating goats (Prosser et al., 1990). It is therefore possible that the reduction in IGF-1 levels contributed to the glucocorticoid-induced inhibition of milk yield.

The decrease in PRL secretion after 2 mammary gland stimulations did not seem to involve glucocorticoids. The depression in milk yield induced by dexamethasone was associated with a decrease in basal PRL concentrations in both serum and milk and with a reduction in milking-induced PRL release. Although, it cannot be ruled out that glucocorticoids reduce milk production partly through the inhibition of PRL secretion or the reduction of mammary gland PRL responsiveness, the fact that enhancement of PRL secretion by domperidone could not prevent the depression of milk yield suggests that other mechanisms are involved.

\section{ACKNOWLEDGMENTS}

The authors thank the following people from Agriculture and Agri-Food Canada at the Sherbrooke Research and Development Centre (Sherbrooke, QC, Canada): Véronique Roy, Frédéric Beaudoin, and Marie-Pascale Morin for providing technical assistance, and the dairy barn staff for taking care of the cows. The authors are grateful to Mary Varcoe, from the Translation Bureau, Public Works and Government Services Canada, for her careful editing of this manuscript. The authors also thank the National Hormone and Peptide Program and A. F. Parlow for providing the bovine PRL and antibodies. This research was financially supported by Agriculture and Agri-Food Canada, Dairy Farmers of Canada, and the National Sciences and Engineering Research Council of Canada (Ottawa, ON, Canada).

\section{REFERENCES}

Abraham, G., M. Allersmeier, J. Gottschalk, G. F. Schusser, H.-O. Hoppen, and F. R. Ungemach. 2009. Effects of dermal dexamethasone application on ACTH and both basal and ACTH-stimulated cortisol concentration in normal horses. J. Vet. Pharmacol. Ther. 32:379-387.

Agnes, F., P. Sartorelli, G. B. Picotti, C. Arrigoni, and A. Locatelli. 1990. Metyrapone and adrenal responses in stressed calves. Zentralbl. Veterinarmed. A 37:771-774. 
Bernier-Dodier, P., C. L. Girard, B. G. Talbot, and P. Lacasse. 2011. Effect of dry period management on mammary gland function and its endocrine regulation in dairy cows. J. Dairy Sci. 94:4922-4936.

Burnstein, K. L., and J. A. Cidlowski. 1992. The down side of glucocorticoid receptor regulation. Mol. Cell. Endocrinol. 83:C1-C8.

de Kloet, E. R., E. Vreugdenhil, M. S. Oitzl, and M. Joëls. 1998. Brain corticosteroid receptor balance in health and disease. Endocr. Rev. 19:269-301.

Feldman, S., and J. Weidenfeld. 1995. Neural mechanisms involved in the corticosteroid feedback effects on the hypothalamo-pituitaryadrenaocortical axis. Prog. Neurobiol. 45:129-141.

Fisher, A. D., M. A. Crowe, E. M. Ó. Nualláin, M. L. Monaghan, D. J. Prendiville, P. O'Kiely, and W. J. Enright. 1997. Effects of suppressing cortisol following castration of bull calves on adrenocorticotropic hormone, in vitro interferon- $\gamma$ production, leukocytes, acute-phase proteins, growth, and feed intake. J. Anim. Sci. 75:1899-1908.

Flint, D. J., and C. H. Knight. 1997. Interactions between prolactin and growth hormone $(\mathrm{GH})$ in the regulation of mammary gland function and epithelial cell survival. J. Mammary Gland Biol. Neoplasia 2:41-48.

Groner, B. 2002. Transcription factor regulation in mammary epithelial cells. Domest. Anim. Endocrinol. 23:25-32.

Hartmann, P. E., and D. S. Kronfeld. 1973. Mammary blood flow and glucose uptake in lactating cows given dexamethasone. J. Dairy Sci. 56:896-902.

Horváth, K. M., Z. Bánky, B. E. Tóth, B. Halász, and G. M. Nagy. 2001. Effect of adrenalectomy and dexamethasone treatment on prolactin secretion of lactating rats. Brain Res. Bull. 56:589-592.

Huizenga, N. A. T. M., J. W. Koper, P. de Lange, H. A. P. Polis, R. P. Stolk, D. E. Grobbee, F. H. de Jong, and S. W. J. Lamberts. 1998. Interperson variability but intraperson stability of baseline plasma cortisol concentrations, and its relation to feedback sensitivity of the hypothalamo-pituitary adrenal axis to a low a dose of dexamethasone in elderly individuals. J. Clin. Endocrinol. Metab. $83: 47-54$.

Keller-Wood, M. E., and M. F. Dallman. 1984. Corticosteroid inhibition of ACTH secretion. Endocr. Rev. 5:1-24.

Koopmans, R. P., M. C. Braat, B. Oosterhuis, and C. J. van Boxtel. 1992. Time-dependent effects of dexamethasone administration on the suppression of plasma hydrocortisone, assessed with a pharmacokinetic model. J. Pharmacol. Exp. Ther. 262:503-508.

Koprowski, J. A., and H. A. Tucker. 1973. Serum prolactin during various physiological states and its relationship to milk production in the bovine. Endocrinology 92:1480-1487.

Kuo, T., A. McQueen, T.-C. Chen, and J.-C. Wang. 2015. Regulation of glucose homeostasis by glucocorticoids. Pages 99-126 in Glucocorticoid Signaling. Vol. 872. J.-C. Wang and C. Harris, ed. Springer, New York, NY.

La Torre, D., and A. Falorni. 2007. Pharmacological causes of hyperprolactinemia. Ther. Clin. Risk Manag. 3:929-951.

Lacasse, P., V. Lollivier, R. M. Bruckmaier, Y. R. Boisclair, G. F. Wagner, and M. Boutinaud. 2011. Effect of the prolactin-release inhibitor quinagolide on lactating dairy cows. J. Dairy Sci. 94:1302-1309.

Lacasse, P., and S. Ollier. 2014. Effect of premilking stimulation and milking frequency on milking-induced prolactin release in lactating dairy cows. Domest. Anim. Endocrinol. 47:47-54.

Lacasse, P., and S. Ollier. 2015. The dopamine antagonist domperidone increases prolactin concentration and enhances milk production in dairy cows. J. Dairy Sci. 98:7856-7864.
Lacasse, P., S. Ollier, V. Lollivier, and M. Boutinaud. 2016. New insights into the importance of prolactin in dairy ruminants. J. Dairy Sci. 99:864-874

Maciel, S. M., C. S. Chamberlain, R. P. Wettemann, and L. J. Spicer. 2001. Dexamethasone influences endocrine and ovarian function in dairy cattle. J. Dairy Sci. 84:1998-2009.

Miller, A. H., R. L. Spencer, M. Pulera, S. Kang, B. S. McEwen, and M. Stein. 1992. Adrenal steroid receptor activation in rat brain and pituitary following dexamethasone: Implications for the dexamethasone suppression test. Biol. Psychiatry 32:850-869.

Miller, A. R. E., R. A. Erdman, L. W. Douglass, and G. E. Dahl. 2000. Effects of photoperiod manipulation during the dry period of dairy cows. J. Dairy Sci. 83:962-967.

Ollier, S., F. Beaudoin, N. Vanacker, and P. Lacasse. 2016. Effect of reducing milk production using a prolactin-release inhibitor or a glucocorticoid on metabolism and immune functions in cows subjected to acute nutritional stress. J. Dairy Sci. 99:9949-9961. https://doi.org/10.3168/jds.2016-11711..

Pessina, P., A. Fernández-Foren, E. Cueto, L. Delucchi, V. Castillo, and A. Meikle. 2009. Cortisol secretion after adrenocorticotrophin $(\mathrm{ACTH})$ and dexamethasone tests in healthy female and male dogs. Acta Vet. Scand. 51:33.

Prosser, C. G., I. R. Fleet, A. N. Corps, E. R. Froesch, and R. B. Heap. 1990. Increase in milk secretion and mammary blood flow by intraarterial infusion of insulin-like growth factor-I into the mammary gland of the goat. J. Endocrinol. 126:437-443.

Sakai, S., and M. R. Banerjee. 1979. Glucocorticoid modulation of prolactin receptors on mammary cells of lactating mice. Biochim. Biophys. Acta 582:79-88.

Shamay, A., F. Shapiro, H. Barash, I. Bruckental, and N. Silanikove. 2000. Effect of dexamethasone on milk yield and composition in dairy cows. Ann. Zootech. 49:343-352.

Skarda, J., E. Urbanova, L. M. Houdebine, C. Delouis, and J. Bilek. 1982. Effects of insulin, cortisol and prolactin on lipid, protein and casein syntheses in goat mammary tissue in organ culture. Reprod. Nutr. Dev. 22:379-386.

Soma, L. R., C. E. Uboh, Y. Luo, F. Guan, P. J. Moate, and R. C. Boston. 2005. Pharmacokinetics of dexamethasone with pharmacokinetic/pharmacodynamic model of the effect of dexamethasone on endogenous hydrocortisone and cortisone in the horse. J. Vet. Pharmacol. Ther. 28:71-80.

Taylor, A. D., A.-M. Cowell, R. J. Flower, and J. C. Buckingham. 1995. Dexamethasone suppresses the release of prolactin from the rat pituitary gland by lipocortin 1 dependent and independent mechanisms. Neuroendocrinology 62:530-542.

Toutain, P. L., R. A. Brandon, M. Alvinerie, R. Garcia-Villar, and Y. Ruckebusch. 1982. Dexamethasone in cattle: Pharmacokinetics and action on the adrenal gland. J. Vet. Pharmacol. Ther. 5:33-43.

van der Schoot, P., and W. J. de Greef. 1983. Effect of adrenalectomy on the regulation of gonadotrophins and prolactin in the lactating rat. J. Endocrinol. 98:227-232.

Vilela, F. C., and A. Giusti-Paiva. 2011. Glucocorticoids disrupt neuroendocrine and behavioral responses during lactation. Endocrinology 152:4838-4845.

Weiner, M. F. 1989. Age and cortisol suppression by dexamethasone in normal subjects. J. Psychiatr. Res. 23:163-168.

Yokoyama, K., M. Hayashi, C. Mogi, Y. Sasakawa, G. Watanabe, K. Taya, S. Devnath, and K. Inoue. 2008. Dose-dependent effects of a glucocorticoid on prolactin production. Endocr. J. 55:405-414. 